\title{
Comparative Factors in Spark Ignition (SI) and Compression Ignition (CI) Engines for A Sustainable Technological Economy
}

\author{
Engr. Joseph O. Amaechi ${ }^{1}$, Thomas, Chinujinim Godstime ${ }^{2}$, Ochogba, Chukwumela Obulor ${ }^{3}$ \\ ${ }^{1}$ Faculty of Vocational and Technical Education, Ignatius Ajuru University of Education Portharcourt River State, Nigeria \\ ${ }^{2}$ Faculty of Science and Technical Education, River State University of Science And Technology, Portharcourt, Nigeria
}

\begin{abstract}
This article titled Comparative factors in spark ignition and compression ignition engines for sustainable technological economy, compares the differences between the both types of internal combustion engines, with respect to their working principles. The spark ignition (SI) engines, uses petrol or gasoline as fuel, while in compression ignition (CI) engines, diesel is used as fuel. Petrol engines are lightweight and achieve higher speed while diesel engines, on the other hand, are heavy engines and achieve lesser speeds. The most prominent difference between Spark Ignition (SI) and Compression Ignition (CI) engines is the type of fuel used and the process of mixing the fuel for effective combustion. The spark ignition engine uses carburetor as a means of mixing the air and fuel in equal proportion while compression engines uses injector.
\end{abstract}

Keywords: spark ignition, compression ignition, internal combustion engines, fuel, and sustainable economy

\section{Introduction}

The term spark-ignition (SI) engine refers to internal combustion engines, generally petrol engines, where the combustion process of the air-fuel mixture is ignited by a spark from a spark plug. This is in contrast to compressionignition (CI) engines, typically diesel engines, where the heat generated from compression is enough to initiate the combustion process, without needing any external spark (William \& Donald, 2007).
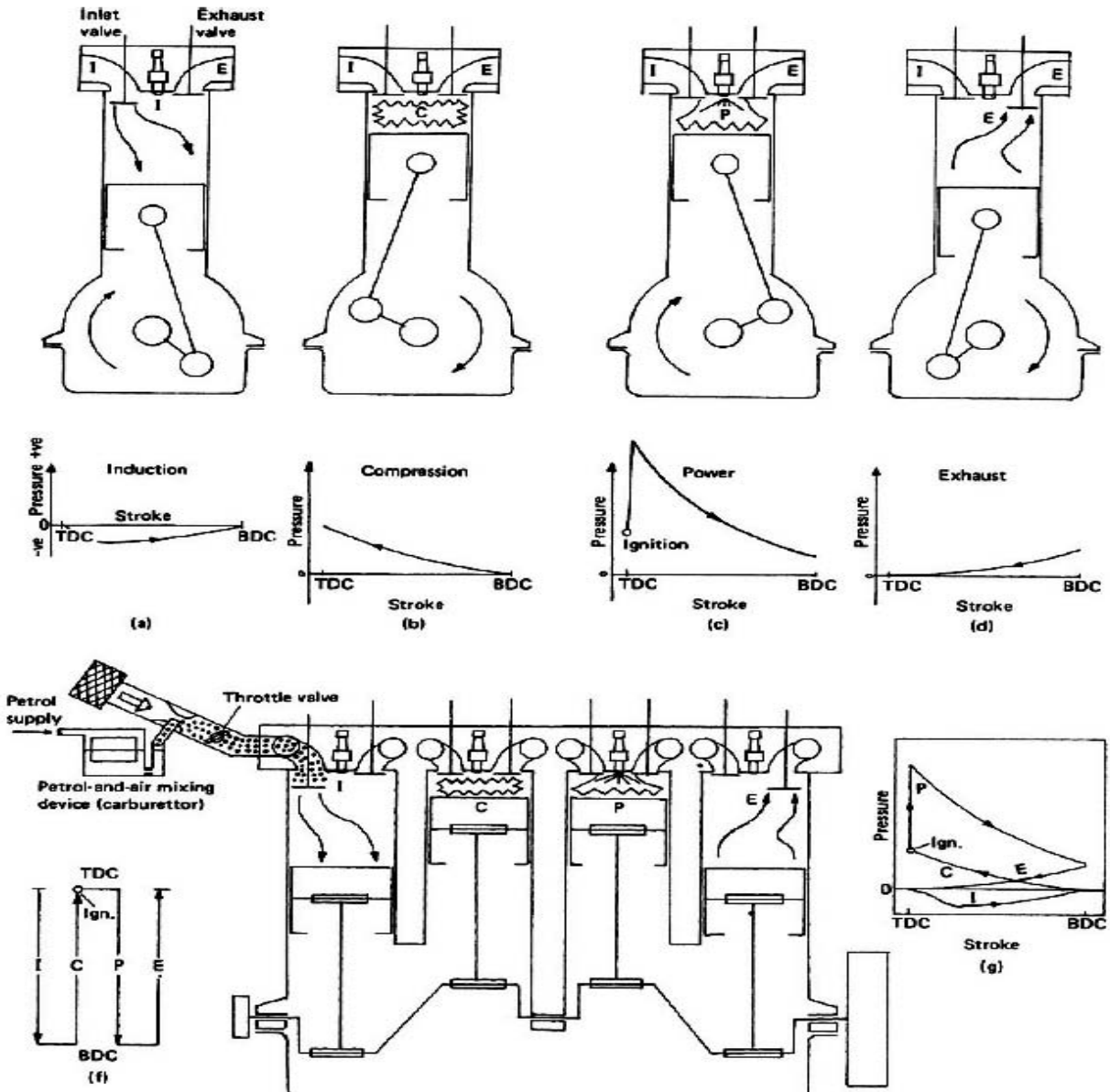

(d)

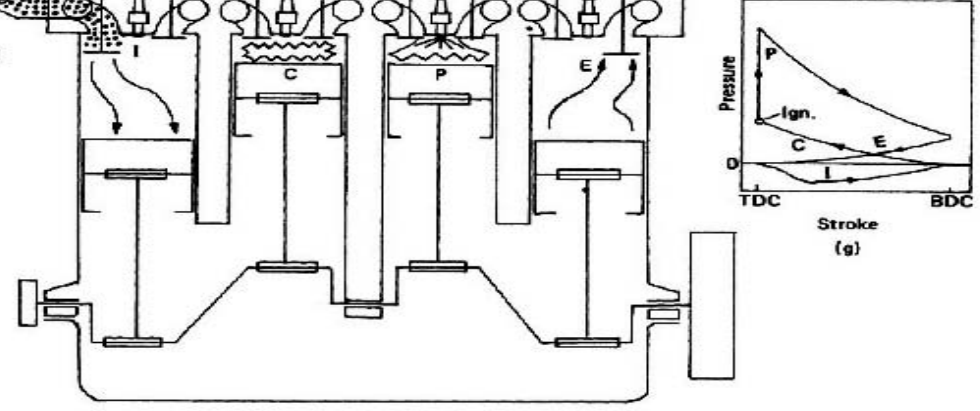

(b)

Fig 1.1-3 Four-stroke-cycle petrol engine.

Figure 1: Diagrammatic layout of four-stroke-cycle petrol engine adopted from Delphi, (2011)

Volume 4 Issue 12, December 2015

www.ijsr.net 


\section{International Journal of Science and Research (IJSR) \\ ISSN (Online): 2319-7064}

Index Copernicus Value (2013): 6.14 | Impact Factor (2014): 5.611

The diesel engine (also known as a compression-ignition engine) is an internal combustion engine in which ignition of the fuel that has been injected into the combustion chamber is initiated by the high temperature which a gas achieves when greatly compressed (adiabatic compression). This contrasts with spark-ignition engines such as a petrol engine (gasoline engine) or gas engine (using a gaseous fuel as opposed to gasoline), which use a spark plug to ignite an airfuel mixture.
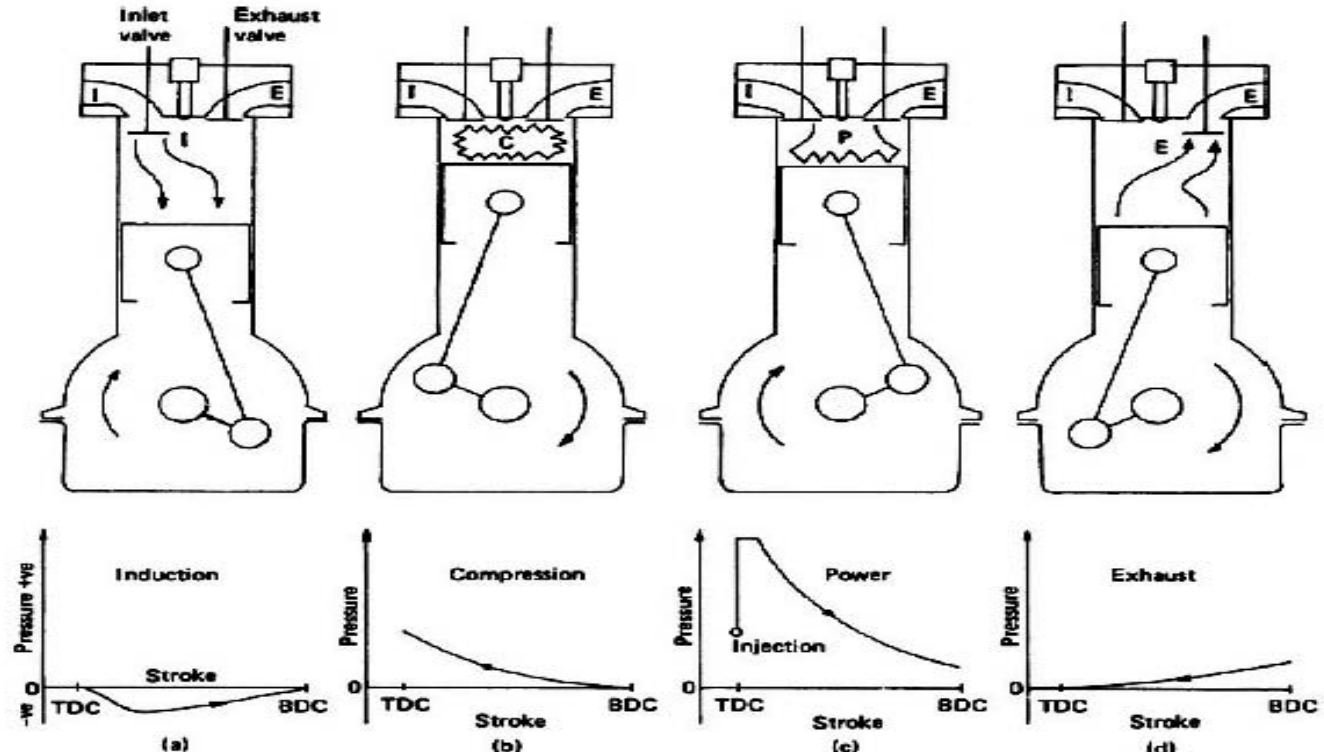

(a)

(b)

(c)
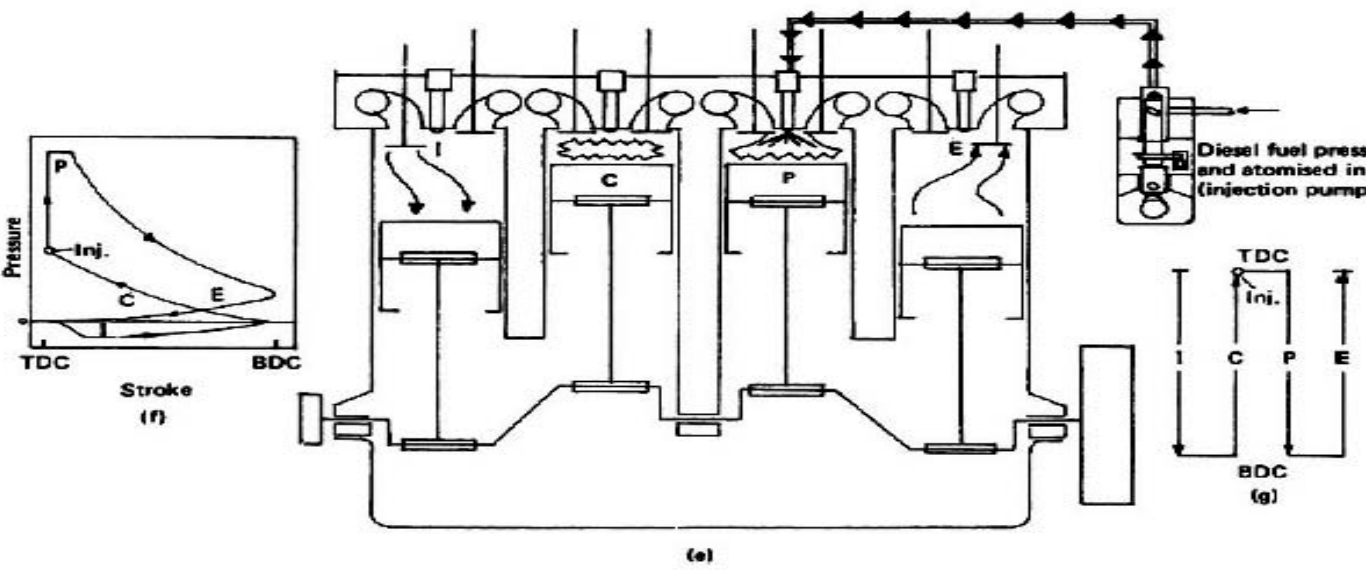

in

Fig. 1.1-8 Four-stroke-cycle diesel engine.

Figure 2: Diagrammatic layout of four-stroke-cycle diesel engine adopted from Delphi, (2011)

\section{Comparative Factors Between Spark Ignition And Compression Ignition Engines}

There are major factors for comparisons between the SI and $\mathrm{CI}$ engines in a developing automotive economy like Nigeria, these are discussed below:

\section{Cycles of Operation}

\section{1) Otto cycle}

Otto cycle is the typical cycle for most of the cars internal combustion engines that work using gasoline as a fuel. Otto cycle is exactly the same as was described for the fourstroke engine. It consists of the same four major steps: Intake, compression, power and exhaust.

\section{2) Diesel cycle}

Most truck and automotive diesel engines use a cycle reminiscent of a four-stroke cycle, but with a compression heating ignition system, rather than needing a separate ignition system. This variation is called the diesel cycle. In the diesel cycle, diesel fuel is injected directly into the cylinder so that combustion occurs at constant pressure, as the piston moves.

\section{a) Type of Fuel}

The most prominent difference between Spark Ignition (SI) and Compression Ignition (CI) engines is the type of fuel used in each. In SI engines petrol or gasoline is used as fuel, hence these engines are also called petrol engines. In CI engines diesel is used as fuel, hence they are also called diesel engines.

\subsection{Quality and variety of fuels}

Setright (2011), maintained that petrol/gasoline engines are limited in the variety and quality of the fuels they can burn. Older petrol engines fitted with a carburetor required a volatile fuel that would vaporize easily to create the necessary air-fuel ratio for combustion. Because both air and fuel are admitted to the cylinder, if the compression ratio of 


\section{International Journal of Science and Research (IJSR) \\ ISSN (Online): 2319-7064}

Index Copernicus Value (2013): 6.14 | Impact Factor (2014): 5.611

the engine is too high or the fuel is too volatile (with too low an octane rating), the fuel ignites under compression, as in a diesel engine, before the piston reaches the top dead center. This pre-ignition causes a power loss and over time causes major damage to the piston and cylinder walls. The need for a fuel that is volatile enough to vaporize but not too volatile (to avoid pre-ignition), this means that petrol engines will only run on a moderate range of fuels. There has been some success at dual-fuel engines that use petrol and ethanol, petrol and propane, and petrol and methane (Suzuki, 1997).

In diesel engines, a mechanical injector system vaporizes the fuel directly into the combustion chamber or a precombustion chamber (as opposed to a Venturi jet in a carburetor, or a fuel injector in a fuel injection system, vaporizing fuel into the intake manifold or intake runners as in a petrol engine). This forced vaporization means that lessvolatile fuels can be used. More crucially, because only air is inducted into the cylinder in a diesel engine, the compression ratio can be much higher as there is no risk of pre-ignition provided the injection process is accurately timed. This means that cylinder temperatures are much higher in a diesel engine than a petrol engine, allowing less volatile fuels to be used (Suzuki, 1997)

\subsection{Fuel flammability}

Diesel fuel has low flammability, leading to a low risk of fire caused by fuel in a vehicle equipped with a diesel engine. In fact, diesel engines are often used than the petrol (gasoline), because the fuels spark-ignition engines releases combustible vapors which can lead to an explosion if it accumulates in a confined space such as the bottom of a vessel. Ventilation systems are mandatory on petrolpowered vessels.

\subsection{Introduction of fuel in the engine}

During the pistons' suction stroke in SI engines a mixture of air and fuel is injected from the cylinder head portion. The air-fuel mixture is injected via the carburetor which controls the quantity and the quality of the injected mixture. In the case of CI engines, diesel is injected into the combustion chamber towards the end of the compression stroke. The fuel starts burning instantly due to the high pressure. To inject fuel in SI engines, a fuel pump and injector are required. In CI engines, the quantity of fuel to be injected is controlled but the quantity of air to be injected is not controlled (Singal, 2012)

\subsection{Fuel Economy}

The chief comparison to be made between the two types of engine is how effectively each engine can convert the liquid fuel into work energy. Different engines are compared by their thermal efficiencies.

Thermal efficiency is the ratio of the useful work produced to the total energy supplied. According to Singer, Charles Joseph; Raper, Richard, (1978) petrol engines can have thermal efficiencies ranging between $12 \%$ and $30 \%$. The corresponding diesel engines generally have improved efficiencies, between $30 \%$ and $40 \%$. Both sets of efficiency values are considerably influenced by the chosen compression-ratio and design.

However, such a comparison does not take into account that diesel fuel is denser and contains about $15 \%$ more energy by volume. Although the calorific value of the fuel is slightly lower at $45.3 \mathrm{MJ} / \mathrm{kg}$ (mega joules per kilogram) than petrol at $45.8 \mathrm{MJ} / \mathrm{kg}$, liquid diesel fuel is significantly denser than liquid petrol. This is significant because volume of fuel, in addition to mass, is an important consideration in mobile applications. Adjusting the numbers to account for the energy density of diesel fuel, the overall energy efficiency is still about $20 \%$ greater for the diesel version.

While a higher compression ratio is helpful in raising efficiency, diesel engines are much more efficient than gasoline (petrol) engines when at low power and at engine idle. Unlike the petrol engine, diesels lack a butterfly valve (throttle) in the inlet system, which closes at idle. This creates parasitic loss and destruction of availability of the incoming air, reducing the efficiency of petrol engines at idle. In many applications, such as marine, agriculture, and railways, diesels are left idling and unattended for many hours, sometimes even days. These advantages are especially attractive in locomotives (Ransome-Wallis, 2001).

Even though diesel engines have a theoretical fuel efficiency of $75 \%$, in practice it is lower. Engines in large diesel trucks, buses, and newer diesel cars can achieve peak efficiencies around $45 \%$, and could reach $55 \%$ efficiency in the near future. However, average efficiency over a driving cycle is lower than peak efficiency. For example, it might be $37 \%$ for an engine with a peak efficiency of $44 \%$ (Autonews.com, 2015).

\section{Ignition Processes}

Internal combustion engines require ignition of the mixture, either by spark ignition (SI) or compression ignition (CI). Before the invention of reliable electrical methods, hot tube and flame methods were used. Experimental engines with laser ignition have been built.

\subsection{Spark Ignition Process}

Gasoline engine ignition systems generally rely on a combination of alternator or generator and lead-acid battery for electrical power. The battery supplies electrical power for cranking, and supplies electrical power when the engine is off. The battery also supplies electrical power during rare run conditions where the alternator cannot maintain more than 13.8 volts (for a common $12 \mathrm{~V}$ automotive electrical system). As alternator voltage falls below 13.8 volts, the lead-acid storage battery increasingly picks up electrical load. During virtually all running conditions, including normal idle conditions, the alternator supplies primary electrical power.

Some systems disable alternator field (rotor) power during wide open throttle conditions. Disabling the field reduces alternator pulley mechanical loading to nearly zero,

\section{Volume 4 Issue 12, December 2015}




\section{International Journal of Science and Research (IJSR) \\ ISSN (Online): 2319-7064}

Index Copernicus Value (2013): 6.14 | Impact Factor (2014): 5.611

maximizing crankshaft power. In this case the battery supplies all primary electrical power.

Gasoline engines take in a mixture of air and gasoline and compress it to not more than 12.8 bar $(1.28 \mathrm{MPa})$. When mixture is compressed, as the piston approaches the cylinder head and maximum stroke, a spark plug ignites the mixture.

The necessary high voltage, typically 10,000 volts to over 30,000 volts, is supplied by an induction coil or transformer. The induction coil is a fly-back system, using interruption of electrical primary system current through some type of synchronized interrupter. The interrupter can be either contact points or a power transistor. Some ignition systems are capacitive discharge types. CD ignitions use step-up transformers. The step-up transformer uses energy stored in a capacitance to generate electric spark. With either system, a mechanical or electrical control system provides a carefully timed high-voltage to the proper cylinder. This spark, via the spark plug, ignites the air-fuel mixture in the engine's cylinders.

Gasoline internal combustion engines are much easier to start in cold weather than diesel engines they can still have cold weather starting problems under extreme conditions.

For years the solution was to park the car in heated areas. In some parts of the world the oil was actually drained and heated over night and returned to the engine for cold starts. In the early 1950s the gasoline Gasifier unit was developed, where, on cold weather starts, raw gasoline was diverted to the unit where part of the fuel was burned causing the other part to become a hot vapor sent directly to the intake valve manifold. This unit was quite popular until electric engine block heaters became standard on gasoline engines sold in cold climates (Zhao, 2010)

\subsection{Diesel Ignition Process}

Diesel engines and Homogeneous charge compression ignition (HCCI) engines rely solely on heat and pressure created by the engine in its compression process for ignition. The compression level that occurs is usually twice or more than a gasoline engine. Diesel engines take in air only, and shortly before peak compression, spray a small quantity of diesel fuel into the cylinder via a fuel injector that allows the fuel to instantly ignite. HCCI type engines take in both air and fuel, but continue to rely on an unaided auto-combustion process, due to higher pressures and heat. This is also why diesel and HCCI engines are more susceptible to coldstarting issues, although they run just as well in cold weather once started. Light duty diesel engines with indirect injection in automobiles and light trucks employ glow plugs that pre-heat the combustion chamber just before starting to reduce no-start conditions in cold weather. Most diesel engines also have a battery and charging system; nevertheless, this system is secondary and is added by manufacturers as a luxury for the ease of starting, turning fuel on and off (which can also be done via a switch or mechanical apparatus), and for running auxiliary electrical components and accessories. Most new engines rely on electrical and electronic engine control units (ECU) that also adjust the combustion process to increase efficiency and reduce emissions (Manbw.com, 2015).

\section{Emissions}

According to Singer, Charles Joseph; Raper, Richard (2013), since the diesel engine uses less fuel than the petrol engine per unit distance, the diesel produces less carbon dioxide $\left(\mathrm{CO}_{2}\right)$ per unit distance.

\subsection{Pollution}

Diesel exhaust is well known for its characteristic smell; but this smell in recent years has become much less because the sulfur is now removed from the fuel in the oil refinery. Diesel exhaust has been found to contain a long list of toxic air contaminants. Among these pollutants, fine particle pollution is perhaps the most important as a cause of diesel's harmful health effects. The products of combustion coming out of the exhaust system are more noticeable with diesel engines, particularly if any of the injection equipment components are out of tune. It is questionable which are the more harmful: the relatively invisible exhaust gases from the petrol engine, which include nitrogen dioxide or the visible smoky diesel, exhaust gases.

\subsection{Noise}

The distinctive noise of a diesel engine is variably called diesel clatter, diesel nailing, or diesel knock. According to Manbw.com (2008), diesel clatter is caused largely by the diesel combustion process; the sudden ignition of the diesel fuel when injected into the combustion chamber causes a pressure wave. Diesel fuels with a higher cetane rating modify the combustion process and reduce diesel clatter.

A combination of improved mechanical technology such as multi-stage injectors which fire a short "pilot charge" of fuel into the cylinder to initiate combustion before delivering the main fuel charge, higher injection pressures that have improved the atomisation of fuel into smaller droplets, and electronic control (which can adjust the timing and length of the injection process to optimise it for all speeds and temperatures), have partially mitigated these problems in the latest generation of common-rail designs, while improving engine efficiency (Anyebe, 2009).

\section{Cost}

Due to their heavy construction and injection equipment, diesel engines are more expensive than petrol engines.

\subsection{Maintenance Hazards}

Fuel injection introduces potential hazards in engine maintenance due to the high fuel pressures used. Residual pressure can remain in the fuel lines long after an injectionequipped engine has been shut down. This residual pressure must be relieved, and if it is done so by external bleed-off, the fuel must be safely contained. If a high-pressure diesel fuel injector is removed from its seat and operated in open air, there is a risk to the operator of injury by hypodermic jet-injection, even with only 100 pounds per square inch $(690 \mathrm{kPa})$ pressure. The first known of such injury occurred in 1937 during a diesel engine maintenance operation (Setright, 2011).

\section{Volume 4 Issue 12, December 2015}




\section{International Journal of Science and Research (IJSR) \\ ISSN (Online): 2319-7064 \\ Index Copernicus Value (2013): 6.14 | Impact Factor (2014): 5.611}

\subsection{Safety}

Unlike petrol, diesel fuels are not flammable at normal operating temperature, so they are not a handling hazard and fire risks due to accidents are minimized. However, after a week-long meeting of international experts, the International Agency for Research on Cancer (IARC), which is part of the World Health Organization (WHO), classified diesel engine exhaust as carcinogenic to humans (Group 1), based on sufficient evidence that exposure is associated with an increased risk for bladder cancer (PRESS RELEASE, June $12,2012)$

\section{Functionality}

\subsection{Torque}

Diesel engines produce more torque than petrol engines for a given displacement due to their higher compression ratio. Higher pressure in the cylinder and higher forces on the connecting rods and crankshaft require stronger, heavier components. Heavier rotating components prevent diesel engines from revolving as high as petrol engines for a given displacement. Diesel engines generally have similar power and inferior power to weight to petrol engines. Petrol engines must be geared lower to get the same torque as a compared to diesel, but since petrol engines revolves higher, both of them will have similar acceleration. Comparing engines based on (maximum) torque is just as useful as comparing them based on (maximum) rpm. (Autonews.com, 2015)

\subsection{Power}

In diesel engines, conditions in the engine differ from the spark-ignition engine, since power is directly controlled by the fuel supply, rather than by controlling the air supply. The average diesel engine has a poorer power-to-weight ratio than the petrol engine. This is because the diesel must operate at lower engine speeds and because it needs heavier, stronger parts to resist the operating pressure caused by the high compression ratio of the engine and the large amounts of torque generated to the crankshaft.

A petrol engine of similar size cannot put out a comparable power increase without extensive alterations because the stock components cannot withstand the higher stresses placed upon them. Since a diesel engine is already built to withstand higher levels of stress, it makes an ideal candidate for performance tuning at little expense. However, it should be said that any modification that raises the amount of fuel and air put through a diesel engine will increase its operating temperature, which will reduce its life and increase service requirements. These are issues with newer, lighter, highperformance diesel engines which are not "overbuilt" to the degree of older engines and they are being pushed to provide greater power in smaller engines (Hardenberg, 1999)

\subsection{Forced induction}

The addition of a turbocharger or supercharger to the engine greatly assists in increasing fuel economy and power output, mitigating the fuel-air intake speed limit for a given engine displacement. Boost pressures can be higher on diesels than on petrol engines, due to the latter's susceptibility to knock, and the higher compression ratio allows a diesel engine to be more efficient than a comparable spark ignition engine. Because the burned gases are expanded further in a diesel engine cylinder, the exhaust gas is cooler, meaning turbochargers require less cooling, and can be more reliable, than with spark-ignition engines (Singer, Charles Joseph; Raper, Richard, 2013)

Poor power and narrow torque bands have been addressed by superchargers, turbochargers, (especially variable geometry turbochargers), intercoolers, and a large efficiency increase from about $35 \%$ for IDI to $45 \%$ for the latest engines in the last 15 years (Fiat.com, 2015).

\subsection{Reliability}

For most industrial or nautical applications, reliability is considered more important than light weight and high power. The lack of an electrical ignition system greatly improves the reliability of CI engine. The high durability of a diesel engine is due to its overbuilt nature, a benefit that is magnified by the lower rotating speeds in diesels. Diesel fuel is a better lubricant than petrol and thus, it is less harmful to the oil film on piston rings and cylinder bores; it is routine for diesel engines to cover $400,000 \mathrm{~km}(250,000 \mathrm{mile})$ or more without a rebuild (Ricardo, 2011).

Due to the greater compression ratio and the increased weight of the stronger components, starting a diesel engine is harder than starting a gasoline engine of similar design and displacement.

According to Nunny, (2007) the pony engine heated the diesel to aid in ignition and used a small clutch and transmission to spin up the diesel engine. Even more unusual was an International Harvester design in which the diesel engine had its own carburetor and ignition system, and started on petrol.

\section{Conclusion}

There is reduced risk of fire accident due to low volatility of diesel fuel and the long intervals between overhauling and servicing also reduces cost of maintenance in CI engines. There is also higher thermal efficiency, greater volumetric efficiency and injection equipments are more reliable and stable in CI than the electrical ignition system in SI engines. The CI engines has less harmful effect of exhaust products, could run without battery which makes it more economical as compared to its size due to high compression ratio.

Spark ignition and compression ignition are totally different mechanical technologies that are used in internal combustion engines. Though, both the spark ignition technology which are called spark ignition (SI) engines, and the other which are known as compression ignition (CI) engines, operates in similarity in some cases using the same principles of operation.

\section{Volume 4 Issue 12, December 2015}




\section{References}

[1] Anyebe, E.A. (2009). Combustion Engine and Operations, Automobile Technology Handbook 2.

[2] Combustion in IC (Internal Combustion) Engines. pp. Slide 37. Archived from the original on April 30, 2005. Retrieved may11, 2015.

[3] Diesel Fuel Injection - How-It-Works. Diesel Power. June 2007. Retrieved April 24, 2015.

[4] Hardenberg, H.O. (2009). The Middle Ages of the Internal Combustion Engine. US: Society of Automotive Engineers.

[5] IARC: DIESEL ENGINE EXHAUST CARCINOGENIC" (PRESS RELEASE June 12, 2012). International Agency for Research on Cancer (IARC). Retrieved June 12, 2015.

[6] Man Diesel Se - Press->Press \& Trade Press Releases$>$ Trade Press Releases ->Stationary Power->MediumSpeed". Manbw.com. November 19, 2008. Archived from the original on November 18, 2010. Retrieved from: http://www.Manbw.com/article_009496.html

[7] Mitsubishi Heavy Industries Technical Review Vol.45 No.1 (2008). Archived from the original on October 4, 2010. Retrieved May 11, 2015

[8] News and events. http://www.fiat.com Retrieved May 10, 2015.

[9] New Power train Technologies Conference. Autonews.com. Retrieved May 11, 2015

[10] Noraz al-Khairi, N., Naveenchandran, P. \& Rashid A Aziz, A. (2011). Comparison of HCCI and SI characteristics on Low Load CNG-DI Combustion. Journal of Applied Sciences, (11), 1827-1832. DOI 10.3923/jas.2011.1827.1832

[11]Nunney, M. J. (2007). Light and Heavy Vehicle Technology (4th ed.). Elsevier Butterworth-Heinemann. ISBN 978-0-7506-8037-0.

[12] Ransome-Wallis, J. (2001). Illustrated Encyclopedia of World Railway Locomotives. Courier Dover Publications. p. 28.

[13]Ricardo, H (2011). The High-Speed Internal Combustion Engine. Patents: ES 156621

[14] Setright, L.J.K. (2011). Some unusual engines. London: The Institution of Mechanical Engineers. ISBN 085298-208-9

[15] Singal, R. K. (2012) Internal Combustion Engines. New Delhi, India: Kataria Books

[16] Singer, Charles Joseph; Raper, Richard (2013). In Charles, Singer et al., (eds). A History of Technology: The Internal Combustion Engine. Clarendon Press. pp. $157-176$.

[17] Stone, R. (1992). Introduction to Internal Combustion Engines (2nd ed.). Macmillan.

[18] Suzuki, T. (1997). The Romance of Engines. US: Society of Automotive Engineers. ISBN 1-56091-911-6

[19]Zhao, H. (2010). Advanced Direct Injection Combustion Engine Technologies and Development: Diesel Engines. Wood head Publishing Limited 